Housing, Performance and Activism: Thinking with performance in times of crisis Katie Beswick

Lecturer in Drama, University of Exeter, UK

k.beswick@exeter.ac.uk

ORCiD id: https://orcid.org/0000-0001-7195-4416

Twitter:@ktbez 


\section{Housing, Performance and Activism: Thinking with performance in times of crisis}

Key words: activism, housing, marginality, performance

This special issue uses performance practice to think about the state of the contemporary housing crisis in the UK and internationally. It draws on Donna Haraway's assertion that, especially in times of enduring trouble across ecological, economic and social spheres, '[i]t matters what thoughts think thoughts. [...] It matters what worlds world worlds' $(2016,34)$. The pervasive ideology of neoliberalism, currently undergoing its own crisis, has resulted in cultural, social and political worlds where obsession with numbers, with measurement, as an extension of an overreliance on the free market, pervades all areas of our lives. Numbers are how we are encouraged to value ourselves and understand how we are valued, from exam scores to salary scales to citation metrics to social media likes. So too our research, in both the fields of housing, performance and elsewhere, is increasingly concerned with measurement, quantification and 'impact', both in the doing and in the evaluation of what has been done. Meanwhile, suspicion of art in all its guises creeps into discourses that structure our daily experiences in the English-speaking world: in the art-washing critiques leveraged at artists working in conditions of gentrification and urban development (discussed in more detail below), in the attack on arts education from governments convinced of STEM's ability to address the crises of neoliberalism, in the insistence that art, time and again, justify itself in economic terms — notwithstanding the frequently evidenced limits of this approach (as illustrated by Belfiore and Bennett 2008 and Belfiore and Upchurch 2013 among others). In this context, it strikes me that the state of performance studies as a marginal and marginalised discipline, where our outputs remain remarkably un-policed by scholars and other readers outside the field, provides us with an unusual amount of freedom to think about our world, 
and indeed, to draw on Haraway's delicious phrase, to world our world, differently — and better.

At its core performance is concerned with the state of being human, not in the sense of a banal, individualistic (and ultimately neoliberal) 'searching for oneself' but in both the philosophical and the physical senses. And, at least at its foundations, performance as practiced and understood within the academic discipline of drama/theatre/performance studies (as opposed to its articulation 'industry' and the training institutions that serve it) is an embodied, collaborative practice of critical thought that is, even when it exists within the neoliberal structures of the university, strangely antithetical to the neoliberal agenda: we start in whatever space is available, getting to know our bodies, anatomically and from within; we start by nurturing (at least ideally) our relationships with one another. So we understand that self and other are always intertwined. There is no self; there is no 'other'. We are concerned with vocal expression: with matters of proximity and emotion. We strive to understand the inner lives of people whose experiences are disconnected from our own. Often, in exercises, we move slowly and with care for those around us. Performance is vitally concerned with being with and with trusting one another: with touch, memory and repetition. Given this, it is perhaps no surprise that, despite our academic discipline's expansion, our embrace and application of continental critical theory and the scholarly development of "performance studies' as a field in its own right, much of our work sits on the periphery of so-called legitimate scholarship: as I allude above, besides a handful of high-profile scholars, performance academics are rarely cited outside our own discipline (or, indeed, within it) (see for example Baker 2018 and data from google metrics). I draw attention to this not to complain about our marginal status — indeed, one of the great betrayals of the neoliberal university system is that it has encouraged us towards preoccupation with how many people have read or mentioned our publications, rather than how deeply those who've read them 
have been moved by what we had to say (but neither do I suggest, in the tradition of the reader-response school of literary criticism, that 'texts without readers are no less complete than readers without texts' (Said 1982, 8). Our thoughts should hope to create thoughts that carry out into the world). Rather this marginal disciplinary position offers us a unique space to vociferously critique and resist the conditions that create our contemporary troubles and their resulting crises for world citizens. Marginality offers us the opportunity to embrace the unique foundations of our discipline in order to think with thoughts that extend beyond those dominating the academic humanities; to break away from the ideas that structure the neoliberal crisis, including those seemingly progressive modes of thinking that have provided useful critical perspectives and accelerated academic careers, but wrought little real change. I evoke bell hooks argument for recognising the inherent politics and the political potential of our emotional desires (1990 and 2001), and for the power of the margin as a radical space of resistance (1989). hooks reminds us of the dangers of pessimism about marginality, 'if we only view the margin as a sign, marking the condition of our pain and deprivation' she writes, 'then a certain hopelessness and despair, a deep nihilism penetrates in a destructive way' (hooks 1989, 21). For hooks, to stay located at the margins when there is a possibility of moving towards the centre is a radical choice; she makes a 'definite distinction between that marginality which is imposed by oppressive structures and that marginality one chooses as site of resistance - as location of radical openness and possibility' (23). While hooks' thoughts emerge from her understanding of colonial power, class relations and racism, and while we as a discipline have work to do in these areas, her thoughts are nonetheless useful in thinking about our own marginality. And perhaps thinking with them to understand the potential of the margin will enable us to move forward in ways that further unfasten our relationships with institutions that perpetuate the violence of colonial power, class inequality and racism. 
By thinking about the margin with hooks' thoughts we can find ways to embrace the marginality of performance (studies), and by recognising what it is that separates us from other disciplines, where we are endlessly misrecognised and misunderstood, we can start think with performance about how we should and might create worlds. We can return to our focus on bodies, spaces, emotions and relationships as foundational. And, as performance is by definition active, despite its marginality we can use performance practice not only to think with, but to take those thoughts out into streets, cities and towns, making changes to overcome injustice and to address our global troubles in large and small ways. The articles in this issue begin to illuminate how thinking with and doing performance can shift our perspectives on crisis; how individual citizens and scholars (and of course citizen-scholars) have thought and acted with performance in conditions of housing crisis across the globe, bringing momentary and enduring shifts - worlding new worlds.

The articles in this collection, then, think with performance practice to address two key questions. The first, 'What can art do for housing activism?' was the title of a long-table event I held, using the format developed by performance-artist and academic Lois Weaver, as part of the Resist festival at the London School of Economics in 2016. This event brought together UK artists, housing activists, residents from a range of precarious housing tenures and academics, using a theatrical method of public engagement (see Split Britches ND) to explore the ways that art might function within fraught housing contexts and alongside activism. The debates that emerged as part of that event reflected the debates that have permeated scholarship and online discussion surrounding art and housing activism in the UK. Although it was clear that the work of artists emerging from conditions of housing crisis was both a means of expression and enjoyment for participants living in crisis and a way to amplify the voices of residents engaged in housing struggles, there was also a deep suspicion of the motivation of artists and academics working in areas undergoing urban development. 
This suspicion is most clearly epitomised by the 'artwashing' critiques (see Pritchard 2017, Harling 2017 and Duman et al. 2018), which have demonstrated how artists profit from the housing crises caused by gentrification. The term 'artwashing' describes how artists can provide a gloss for the violent displacement of communities during urban redevelopment where artworks are often created, commissioned, co-opted or otherwise sanctioned by developers who profit from the cultural capital that artworks afford up-and-coming neighbourhoods. These criticisms of arts practice, while often justified, make it difficult to conceive of ways that art might operate beyond the serving of a neoliberal agenda: impossible to imagine how artists might act autonomously for resistance and progressive change in the face of oppression. Scholars and artists have resisted totalising accusations of artwashing, and drawn attention to the ways that arts practices taking place in fraught housing contexts negotiate the complexities of the neoliberal terrain (see e.g. Berry-Slater and Iles 2011, Harvie 2011, Sachs-Olsen 2017). These arguments often emphasise the ambivalence of works in contexts of crisis and regeneration, and indeed, as I have argued elsewhere (see Beswick 2019, 150), critical ambivalence is a useful tool for understanding how the intersections of sensual practice and structural inequalities work to produce spatial injustice. In this special issue however, what begins to emerge is not an irreconcilable ambivalence between systems of injustice and the practice of artists, but the sense that performance, as a way of thinking as well as a practice, might still yet sometimes be just out of reach of the forces of capital that orchestrate our worlds. The articles illustrate how coming to know through our bodies and our relationships with others are important means of moving through and understanding the trouble of our times.

The second question this issue addresses, 'What is a crisis?' emerges from contemporary scholarship around neoliberalism, precariousness and housing in performance studies (see Angelaki 2017, Fragkou 2018) and elsewhere (including in Haraway's work). 
Here debates have emerged about the usefulness of the term 'crisis' to describe the conditions of late capitalism and their attendant troubles. Cynicism towards articulating the problems of the contemporary moment as crisis, and arguments that crisis is in fact 'embedded in the ordinary' (Berlant 2011: 10); a condition of human existence, are sometimes philosophically persuasive - however they are also dangerous. To deny that what we are experiencing is crisis is also to risk denying that things might be better. Undoubtedly there is a danger in narrating crisis so that it becomes something unconnected to history, something 'which can be measured, controlled and resolved' (Fragkou 2018: 3), there is also a danger, in evading the term crisis, that you suggest that how things are does not call for urgent change. Convincing us that there are 'no alternatives' is late capitalism's most chilling method of enacting structural violence without resistance (Fisher 2012, Madden and Marcuse 2016). Crises does not equal hopelessness (Angelaki 2017: 1-5) but should propel action.

Certainly, when it comes to housing, as David Madden and Peter Marcuse point out, the oppressed have always lived in crisis (2016, 9-10, see also Engles 1872). Nonetheless, the exacerbation of this permanent state of instability, and the threat to housing not only for the poor but for the middle-class and the relatively well off, suggests new and increased troubles specific to the conditions of now. There has been a shift in how we think about homes, houses and the right to shelter over the past three decades, as the global neoliberal project has expanded, bringing with it a reduction in social and affordable rented housing, and expanded demand for ownership (Harvey 2008). This shift is characterised by 'hyper-commodification' (Madden and Marcuse 2016: 56), wherein housing's function as living space becomes subsumed by its function as a financial product, and increasing deregulation and overreliance on the supposed efficiency of the market contribute to speculation, inflated prices, and ever more precarity for the least well off. This hyper-commodified environment, Madden and Marcuse explain, is characterised by 'fear, stress, anxiety and disempowerment' for citizens 
struggling to survive in hostile market-driven conditions. As David Harvey (2008) points out, the neoliberal trend towards owner occupation has exacerbated existing housing crises and resulted in a global crisis of affordable housing. This is regardless of the fact that the right to safe, decent housing is commonly understood as a fundamental human right; enshrined in the Universal Declaration of Human Rights and the International Covenant on Economic, Social and Cultural Rights.

The right to adequate shelter and housing is, globally, under threat. As population growth and the emptying of rural communities leads to congested megacities, housing conditions become increasingly disorganised, unsanitary, and shambolic (Patel and Burke 2009). According to the United Nations Human Rights Office of the High Commissioner, there are over one billion people living in slums and informal settlements, and over100 million 'homeless' people worldwide $(2012,1)$. The collapse of the sub-prime mortgage market (as aspirational homeowners defaulted on unaffordable loans) triggered the 2007/8 financial crisis and subsequent global recession - illustrating how crises of housing are linked to crises of the prevailing economic ideology, and pointing to tectonic cracks in the neoliberal model. Across the world, those unable to keep up with mortgage payments found themselves under threat of eviction or repossession. These conditions have deepened local and global inequality in past decade, paradoxically heralding a boom in speculative development as the market floods in ineffectually to quell the rising crisis, intensifying the displacement and disenfranchisement of those unable to find and sustain secure housing conditions. The articles in this issue show us what it means to be in crisis in different local, global, and cultural contexts.

There are eight articles in this issue, which resonate with one another in ways too complex and too fully expand here (I hope that readers will enjoy finding and making their 
own connections in the rich offering of thoughts, worlds and practices in what follows this introduction); they are loosely grouped into thematic and stylistic sections, though these are not absolute. Part One, 'Performing Crisis', consists of three pieces of shorter experimental performance writing that reveal how individuals have experienced and navigated contemporary conditions of housing crisis in a range of geographical locations. The first, Alex Halligey's “"Home is Home”: Journeying and Living from Ethiopia to Johannesburg' is as a hybrid essay-interview, emerging from the performance-workshops she runs with refugees in the Johannesburg suburb of Bertrams, South Africa. The interview is presented as if it were the script of a play. This performance article offers the housing biography of Mewish, an Ethiopian refugee living in Johannesburg, and reveals how performance writing might usefully enrich our understanding of the nuances of activisms that resist the housing crises; articulating how micro-acts of resistance make up what Ingold (2013) calls a 'meshwork' of actions, through which people in conditions of crisis make changes to improve their daily lives. In 'Performing millennial housing precarity: How (not) to live together' Katheryn Owens and Chris Green, who work as an enduring colloborative team, similarly focus on the micro-daily and its wider political significance. Here the authors present performance-writing that narrates their experience of living in shared housing in the UK. They reveal how conditions of housing crisis structure the experience of the millennial generation, and use experimental performance scripts to uncover the ways in which precarity emerging from structural inequality and injustice might nonetheless afford possibilities for exploration, freedom and play. Andrea Maciel's 'The Ground of the Cities - performance as catalysis' narrates her embodied exploration of vulnerable city dwellers, particularly the street homeless, in cities across the world. Focussing eventually on her experience in Salvador da Bahia, Brazil, she explains how, by falling to the ground in a performative act of resistance that refuses the 'verticality of productive urban life' she changed temporarily the 
rythms of the city in ways that 'generate perceptions and affections', revealing the structural inequalites of social space.

Part Two 'Performing Resistance', uses performativity to think about activism. Cecila Vergano uses performace as a mode of understanding the strands of activism that operate at the via Germagnano Roma camp in Turin, Italy. Recognising the infrapolitical activism evident in acts of violence and vandalism by the Roma in the camp, she also thinks about the possibilties and limits of the more recognisable performance activism of the Clown Army within the camp. Veronica Baxter and Mbogeni Mtshali meanwhile use performance to think about the 'poo protests' in Cape Town, South Africa where residents used shit to protest sanitation conditions in a series of protests between 2011 and 2017. They argue that this slow activism provides generative and productive models of performative resistance, which effectively disrupt the neoliberal order. Further articulating how activism might be thought with performance, Lynne McCarthy offers a reading of the Focus E15 mothers' occupation of empty social housing in Newham, London in October 2014, and the subsequent verbatim theatrical staging of the campaign, The Land of the Three Towers (2014). McCarthy uses performance analysis to demonstrate how the Focus E15 campaign, which protested the social cleansing of young mothers from the borough of Newham as part of its redevelopment, and the subsequent performance, reveal the significance of the feminist voice as a strategy for making claims to property.

The final section, 'Performing Activism', offers two accounts of the use of agitprop performance as resistance to neoliberal injustice in the UK in different contemporary periods. In 'Sheffield's Tenants' Theatres in the 1980s: theatre, community and activism' Bill McDonnell recollects his expereinces working with Sheffield's tenants theatres, communitybuilding with performance to oppose the ideology of Thatcherism at its inception and expose the harms of creeping neoliberalism along with residents of inner city social housing estates 
in Sheffield, England. McDonnell's account makes a case for the importance of performance practice as a collective strategy of resistance, and reveals the successes of the tenants' theatre movement in opposing injustices in Sheffield. McDonnell hints at how collective action through performance might provide a strategy for resistance to the ongoing effects of neoliberalism. The final article of the issue, Rebecca Hillman's 'Home is where the heart is: building, belonging and emotional engagement in anti-austerity performance', develops McDonnell's discussion of the potential of agitprop performance. Based around her work as part of the performance collective In Good Company in Reading, Hillman explores their 2011 performance The Pact, in which issues of housing and home circulated. She proposes that the conditions of rehearsal offer a productive home for political organising, and explores the emotional registers of home, thinking with performance to suggest that audiences' emotional responses to the scenes in the pact were 'integral' to their 'awareness of themselves in society'. Her work reveals the importance of emotion, connection and engagement in activist performance.

In its structure the issue works to offer a progression of ideas; a range of ways to 'think with' performance from which it invites the reader to depart. Many of the accounts in the articles in this issue begin from or with the stories of individual people or families. The storytelling register of many of the articles speaks to one of the vital elements of performance as a discipline: its ability to use narrative and aesthetic strategies in order to confront and experiment with solutions for the problems of the world.

I conceived this special issue as a method for understanding the ways that conditions emerging from the neoliberal housing crisis in the UK resonate globally, and the different challenge the neoliberal housing context poses in different geographical regions. Nonetheless, perhaps because this is an English journal, published in the UK and written in English, it emphasises the English context (as a result of the articles submitted, and 
completed after peer review) — with contributions from scholars in Italy, South Africa and Brazil providing points from which we might expand our understanding of the crisis globally. I hope it gives you new thoughts to think with.

\section{References}

Angelaki, V. 2017. Social and Political Theatre in $21^{\text {st }}$ Century Britan: Staging Crisis. London: Bloomsbury Methuen.

Baker, S. 2018. "How much research goes completely uncited." Times Higher Education, April 18 https://www.timeshighereducation.com/news/how-much-research-goes-completelyuncited

Belfiore, E. and Bennett, O. 2008. The Social Impact of the Arts: An Intellectual History. Basingstoke: Palgrave Macmillan.

Belfiore, E. and Upchurch, A.R 2013. Humanities in the Twenty-First Century: Beyond Utility and Markets. Basingstoke: Palgrave Macmillan.

Berlant, L. 2011. Cruel Optimism. Durham: Duke University Press.

Berry-Slater, J., and Iles, A. 2011. "No room to move: Radical art and the regenerate city", in Social Housing: Housing the Social . . . ment. Amsterdam: SKOR.

Beswick, K. 2019. Social Housing in Performance: The English Council Estate on and off Stage. London: Bloomsbury Methuen

Duman, A., Hancox, D., Malcom, J. and Minton, A. 2018. Regeneration Songs: Sounds of Investment and Loss From East London. New York: Repeater Books.

Fragkou, M. 2018. Ecologies of Precarity in $21^{\text {st }}$ Century Theatre: Politics, Affect, Responsibility. London: Bloomsbury Methuen 
Haraway, D.J. 2016. Staying with the Trouble: making kin in the Chthulucene. Durham: Duke University Press.

Harling, R. 2017. "Balfron Tower the artwashing of an icon." Urban Transcripts Journal, 1(3). http://journal.urbantranscripts.org/article/ balfron-tower-artwash-icon-rab-harling/

Harvey, D. 2008. "The right to the city." New Left Review (53): 23-40.

Harvie, J. 2011. "Democracy and neoliberalism in art's social turn and Roger

Hiorns' seizure.” Performance Research, 16(2): 113-23.

hooks, b. 1989, "Choosing the margin as a space of radical openness." Framework: The Journal of Cinema and Media (36): 15-23. https://www.jstor.org/stable/44111660

hooks, b. 1990, Yearning: Race, Gender, and Cultural Politics. Boston: South End Press.

hooks, b. 2001. All About Love: New Visions. New York: Harper Perennial.

Ingold, T. 2013. Making: anthropology, archaeology, art and architecture. London:

Routledge.

Patel, R.B and Burke, T.F. 2009. "Urbanization - an emerging humanitarian disaster." The New England Journal of Medicine (361): 741-743.

https://www.nejm.org/doi/pdf/10.1056/NEJMp0810878

Pritchard, S. 2017. “Artwashing: Social capital and anti-gentrification activism”, in Colouring in Culture, 17 June.

http://colouringinculture.org/blog/artwashingsocialcapitalantigentrification

Sachs Olsen, C. 2017. "Collaborative challenges: Negotiating the complicities 
of socially engaged art within an era of neoliberal capitalism." Environment

and Planning, 36(2): 273-93.

Said, S. 1982. “Opponents, audeinces, constituencies and communities.” Critical Inquiry 9(1): $1-26$.

Split Britches. ND. “The Longtable”. http://www.split-britches.com/longtable/

United Nations Human Rights Office of the High Commissioner. 2012. Women and the right to adequate housing. United Nations.

https://www.ohchr.org/Documents/publications/WomenHousing_HR.PUB.11.2.pdf 